REVIEW ARTICLE

\title{
Recognizing the importance of sleep-disordered breathing in cerebrovascular disease - an update
}

\author{
Garima Shukla', PR Srijithesh ${ }^{2}$
}

'Department of Neurology, All India Institute of Medical Sciences, New Delhi, India \& ${ }^{2}$ Department of Neurology, Jawaharlal Institute of Postgraduate Medical Education and Research, Puducherry, India

S leep-disordered breathing (SDB) is being increasingly recognized as a vascular risk factor implicated in the whole spectrum of vascular diseases ranging from coronary heart disease and congestive cardiac failure to hypertension and stroke. It is important not only with respect to the magnitude of risk it raises, but also as an effectively treatable risk factor. In the instance of cerebrovascular disease, the evidence has moved from the initial dilemma of SDB as cause or consequence of stroke to that of a definitive risk requiring appropriate means of therapy. In the following review we will be discussing the weight of evidence linking SDB with cerebrovascular disease, and the issues pertaining to evidences generated by treatment trials.

\section{What is Sleep-disordered breathing?}

In the broadest term SDB includes snoring, obstructive sleep apnea and central apnea. However, in sleep medicine parlance, SDB is mainly considered as SnoringUpper airway resistance syndrome-Obstructive sleep apnea spectrum.

Sleep apnea refers to temporary respiratory pauses during sleep. To be of significance it should be 10 seconds or more. Sleep apnea can be obstructive, central or mixed. In obstructive sleep apnea there is cessation of airflow through nose or mouth, but with continuing

\section{Address for correspondence}

\section{Dr. Garima Shukla}

Associate Professor, Dept. of Neurology

Room \# 2, $6^{\text {th }}$ Floor, Neurosciences Center

All India Instt. of Medical Sciences, New Delhi - 29

Phone: +911126593785 Fax: +911126588166

Email: garimashukla@hotmail.com respiratory effort as evidenced by diaphragmatic and intercostals muscle activities. In central apnea, there is no respiratory effort at all. Mixed apnea begins as central apnea with cessation of airflow and respiratory effort, but appears as obstructive apnea towards the end with appearance of respiratory effort, while nasal and mouth airflow show continuing restriction.

Sleep hypopnea is defined as $30 \%$ or more airflow limitation associated with $4 \%$ or more oxygen desaturation. ${ }^{2}$ Sleep apnea and hypopnea are combined together in an index called Apnea-hypopnea or Respiratory disturbance index (AHI or RDI) defined as number of apneas or hypopnea per hour of sleep. Normal AHI is less than 5 .

Obstructive sleep apnea syndrome (OSAS) refers to the polysomnography demonstrated OSA together with the clinical consequences of impaired sleepiness. The diagnostic criteria for OSAS devised by task force of the American Academy of Sleep Medicine is given in table $1^{3}$

In Upper airway resistance syndrome there is no airflow limitation significant enough to cause apneahypopnea and oxygen desaturation, but flow limitation causes recurrent arousals and resultant sleep fragmentation. The UARS cannot be identified by usual PSG recording of respiration using oronasal themistor, but requires nasal pressure monitoring using nasal cannula or better still, by the gold standard, intraoesophageal balloon manometery. Patients with UARS exhibit all the clinical manifestation and consequences of obstructive sleep apnea. ${ }^{4}$

\section{Evolutionary biology}

Sleep-disordered breathing is itself a consequence of features unique to upper airway system of humans. In

Indian Journal of Sleep Medicine (IJSM), Vol. 5, No. 2, 2010 
Table 1: Diagnostic criteria for OSAS

\begin{abstract}
These are as follows:
A) Excessive daytime sleepiness that is not better explained by other factors

- Choking or gasping during sleep

- Recurrent awakenings from sleep

- Unrefreshing sleep

- Daytime fatigue

- Impaired concentration

\section{SEVERITY GRADING}

Mild : 5-15 events/hour of sleep

Moderate : $15-30$ events/hour of sleep

Severe : More than 30 events/hour of sleep

humans, in contrast to other animals, the larynx is much descended, has a narrow distensible supralaryngeal vocal tract, has no epiglottic-soft palate lock-up (allowing a oropharyngeal tongue) and has an acute cranial base angulation all allowing the already compromised upper airway to the mercy of pharyngeal dilator muscle tone. In sleep, there is normal reduction in the pharyngeal dilator tone. This, superimposed on already narrowed and/or compliant pharynx causes upper airway obstruction. T M Davidson who put forward this debate, persuasively argues that sleep apnea is thus the evolutionary price that humans pay for their ability for speech. ${ }^{5}$
\end{abstract}

The patient suspected of OSAS must fulfill criterion A or B, plus criterion C.

B) Two or more of the following that are not better explained by other factors:

C) Overnight monitoring demonstrates five or more obstructed breathing events per hour during sleep. These events may include any combination of obstructive apneas/hypopneas or respiratory effort-related arousals.

\section{OSA and Cerebrovascular diseases - Pathogenetic mechanisms}

The common denominator in the pathogenetic mechanisms described is the intermittent hypoxemia seen in patients with OSA. Repeated intermittent hypoxia is shown to cause diurnal elevation of BP in rats. The resting sympathetic activity in patients with OSA is found to be elevated. There is evidence of endothelial dysfunction, ${ }^{6}$ enhanced release of oxygen free radicals, ${ }^{7,8}$ increased expression of adhesion molecules ${ }^{8}$ and inflammatory mediators, ${ }^{9-12}$ increased lipid peroxidation ${ }^{7}$ and insulin resistance $^{12,13}$ in patients with OSA.. There are also studies showing increased platelet aggregation, increased fibrinogen levels and prothrombotic state in patients with OSA. Most of these- the endothelial dysfunction, the oxidative stress, the plasma NO level, insulin resistance and baseline sympathetic activity- have been shown to improve after treatment with CPAP.

\section{Vascular consequences}

Sleep-disordered breathing is thought to mediate various vascular consequences both by directly acting on the pathogenetic mechanisms and also by indirectly

Table 2

\footnotetext{
Obstructive sleep apnea (OSA): Polysomnography demonstrated obstructive sleep apnea with apnea-hypopnea index more than 5 .

Obstructive sleep apnea syndrome (OSAS): OSA with clinical manifestations of impaired night-time sleep (see Table 1).

Upper airway resistance syndrome (UARS):

- A condition characterized by airflow limitation causing recurrent arousals and sleep fragmentation, but not enough to cause sleep apnea or hypopnea.

- Demonstration requires nasal pressure monitoring using nasal cannula or intraoesophageal balloon manometry.

- Usual polysomnography recording shows recurrent flow-limitation and arousal, but no sleep apnea/hypopnea.

- Associated with all clinical manifestation and consequences of OSA
} 
modulating known risk factors.

In the context of cerebrovascular diseases, the significance of SDB was first recognized when it was found that there was disproportionately high prevalence of SDB in patients with stroke compared with matched normal population. While the community prevalence of OSAS (OSA + EDS with AHI $\geq 5$ ) in the Wisconsin study by Young et al was $4 \%$ in men and $2 \%$ in females, the prevalence of OSA (AHI $\geq 10)$ in stroke patients varies from $44 \%$ to as high as $96 \%$ depending on the setting of the study ( 6 weeks old stroke versus 2 weeks old stroke) (Table 3) ${ }^{17-23}$. With the observation of decreasing prevalence of OSA with increase in duration from stroke, its occurrence was initially attributed to be a consequence of stroke. However, subsequent studies have clearly shown that OSA is, in addition, as an independent risk factor for stroke too.

\section{OSA as an independent risk factor for stroke}

Yaggi et al in an observational cohort study involving 1022 patients with 4 years follow up has shown that hazards ratio (HR) of OSA for stroke or all cause mortality was $2.24(1.3-3.86,95 \% \mathrm{CI})$, well above that for conventional risk factors like hypertension (1.48), diabetes (1.56), hyperlipidemia (1.04) and smoking
(1.23). When the hazards ratio was adjusted for variables like hypertension with which OSA interact, the HR was still significant and more than that due to conventional risk factors (1.97 against 1.09 for hypertension, 1.31 for diabetics and 1.46 for smoking). (Table 4). A trend analysis for the relationship between the severity of OSA and composite outcome of stroke or death from any cause showed that as AHI increases so does the hazards ratio, with patients with $\mathrm{AHI}>36$ having a hazards ratio of 3.3 (1.74-6.26, 95\% CI) (Table 4). ${ }^{24}$ This corroborates the cross sectional results of Sleep Heart Health study, a population based cohort study involving 6424 individuals, showing that the prevalence of stroke, coronary heart disease, hypertension and congestive cardiac failure increases with the severity of OSA as determined by AHI increases. ${ }^{25}$ More recently, in a prospective study on 392 patients with coronary artery disease, $34 \%$ patients had an $\mathrm{AHI}>5$, among which 12\% (47 patients) developed stroke, with the HR for stroke being 2.89 (1.37 -6.09). ${ }^{26}$

Martin et al in an observational study involving 1651 individuals in 5 arms (healthy adults, simple snorers, untreated mild-moderate OSA, untreated severe OSA and severe OSA treated with CPAP) with a mean follow up of 10 years found patients with untreated severe OSA have about 3 times greater incidence of getting fatal and nonfatal cardiovascular events, while the risk of fatal end-points was comparable in simple snorers, patients with untreated

Table 3 : Prevalence of SDB in Stroke

\begin{tabular}{|c|c|c|c|c|}
\hline Study & $\mathrm{N}$ & Criteria for diagnosis & $\begin{array}{l}\text { Time of Sleep } \\
\text { recording from } \\
\text { the stroke onset }\end{array}$ & Prevalence \\
\hline $\begin{array}{l}\text { Bassetti et al } \\
\text { Stroke. 2006; } 37 \\
\text { Prospective Ischemic stroke }\end{array}$ & 152 & PSG & $\begin{array}{l}1-2 \text { days of } \\
\text { stroke }\end{array}$ & $\begin{array}{l}\mathrm{AHI} \geq 10: \\
58 \%\end{array}$ \\
\hline $\begin{array}{l}\text { Parra et al } \\
\text { AJRCCM Feb 2000; } 161 \\
\text { Prevalence study } \\
\text { First-ever Stroke and TIA }\end{array}$ & 161 & $\begin{array}{l}\text { Portable respiration } \\
\text { record device }\end{array}$ & $\begin{array}{l}\text { Acute phase: } \\
48-72 \mathrm{hr} \\
\text { Stable phase: } \\
\text { after } 3 \text { months }\end{array}$ & $\begin{array}{l}\text { Acute phase: } \\
\text { AHI } \geq 10: 71.4 \% \\
\text { Stable phase: } \\
\text { AHI } \geq 10: 61 \%\end{array}$ \\
\hline $\begin{array}{l}\text { Harbison et al } \\
\text { QJM 2000; } 93 \\
\text { Prevalence study } \\
\text { Ischemic stroke }\end{array}$ & 68 & $\begin{array}{l}\text { Portable respiration } \\
\text { record device (ResMed } \\
\text { Autoset II plus system) }\end{array}$ & $\begin{array}{l}2 \text { weeks } \\
\text { 6-9 weeks }\end{array}$ & $\begin{array}{l}2 \text { weeks } \\
96 \% \text { AHI } \geq 10 \\
6-9 \text { weeks } \\
74 \% \text { AHI } \geq 10\end{array}$ \\
\hline $\begin{array}{l}\text { Wessendorf } \\
\text { J Neurol. 2000; } 247 \\
\text { Cross sectional } \\
\text { surveyRehabilitation unit }\end{array}$ & 147 & Full PSG & & $\begin{array}{l}\mathrm{AHI} \geq 10: 44 \% \\
\text { Central apnea: } \\
<6 \%\end{array}$ \\
\hline
\end{tabular}


mild-moderate OSA and severe OSA treated with CPAP. Multivariate analysis showed risk of odds ratio of nonfatal cardiovascular event in untreated severe OSA patients was 3.17 compared to healthy participants (Table 4). ${ }^{27}$

\section{OSA as a risk factor for hypertension}

Peppard et al in a prospective population based studythe Wisconsin sleep cohort study- involving 709 participants in 4 years follow up and 184 participants in 8 years follow up, found that the odds ratio for hypertension in patients with $\mathrm{AHI} \geq 15$ (i.e. moderatesevere OSA as per AASM task force criteria ${ }^{1}$ ) adjusted for baseline hypertension status was 4.54, while that adjusted for age and sex in addition to baseline hypertension status was 4.47 . When the anthropometric parameters of BMI and waist and neck circumference were adjusted to the model the OD was 2.89 , whereas with sequential adjustment for alcohol and cigarette use the OD did not change from the value of 2.89 . Here again there is a progressive increase in risk with increase in AHI. ${ }^{28}$

The adjustment for BMI and waist circumference may not be entirely justifiable as it undermines the cumulative risk of OSA as OSA itself has been found to be a risk factor for the metabolic syndrome, of which increased BMI and waist circumference are components. ${ }^{29,30}$ Similarly, one might undermine the role of OSA as a risk factor for stroke, if adjustment is made

Table 4

\begin{tabular}{|l|l|l|}
\hline \multicolumn{3}{|c|}{ OSA \& Vascular Risks } \\
\hline $\begin{array}{l}\text { Study \& Risk } \\
\text { factors }\end{array}$ & $\begin{array}{l}\text { Unadjusted Risk } \\
(\mathbf{9 5 \%} \mathrm{CI})\end{array}$ & $\begin{array}{l}\text { Adjusted Risk } \\
(\mathbf{9 5 \%} \mathrm{CI})\end{array}$ \\
\hline Yaggi et al & \multicolumn{2}{|c|}{ Odds Ratio } \\
\hline Age & $1.09(1.06-1.11)$ & $1.08(1.06-1.11)$ \\
\hline Smoking & $1.21(0.90-1.64)$ & $1.46(0.78-1.18)$ \\
\hline Hypertension & $1.48(0.95-2.28)$ & $1.19(0.75-1.90)$ \\
\hline OSA & $2.24(1.30-3.86)$ & $1.94(1.12-3.48)$ \\
\hline Atrial fibrillation & $1.56(0.79-3.12)$ & $0.91(0.45-1.86)$ \\
\hline Diabetic mellitus & $1.56(0.79-3.12)$ & $1.31(0.76-2.26)$ \\
\hline JM Martin et al & \multicolumn{2}{|c|}{ Hazards Ratio } \\
\hline Age & $1.11(1.07-1.14)$ & $1.09(1.45-1.13)$ \\
\hline Smoking & $1.97(1.42-6.71)$ & $1.51(1.02-5.88)$ \\
\hline Systolic BP & $1.83(1.24-5.52)$ & $1.57(1.04-4.09)$ \\
\hline Mild-moderate OSA & $1.77(0.91-2.76)$ & $1.57(0.67-3.16)$ \\
\hline Severe OSA & $5.95(1.92-6.52)$ & $3.17(1.12-7.52)$ \\
\hline OSA on CPAP & $1.44(0.61-2.80)$ & $1.42(0.52-3.4)$ \\
\hline Cardiovascular disease & $2.68(1.13-2.57)$ & $1.77(1.03-3.09)$ \\
\hline
\end{tabular}

for hypertension, since OSA, as observed by Peppard et al, raises the risk for hypertension by 3-4 times. Alajmi et al in a meta-analysis of randomized control trials on the effect of CPAP therapy on blood pressure in patients with OSA, concluded that CPAP is not useful in reducing $\mathrm{BP}$ in unselected patients with OSA. However, in patients with severe OSA ( $\mathrm{AHI} \geq 30$ ), there was a definite trend towards greater BP reduction ( Table 5). ${ }^{29}$

Logan et al has reported that in patients whose hypertension was refractory to medical therapy, $87 \%$ had OSA. ${ }^{30}$ The same group has reported a BP reduction to the tune of $10 \mathrm{mmHg}$ in patients with refractory hypertension treated with CPAP. ${ }^{31}$ As with the results of treatment trial of Martin et $\mathrm{al},{ }^{27}$ the effect of treatment of OSA is significant mainly in those with severe disease and studies which did not apply such a selection, did not show any treatment benefit. Also, treatment effect was apparent in studies where the proportion of patients with baseline hypertension was more, while studies on

Table 5

\begin{tabular}{|c|c|c|c|c|c|c|}
\hline \multicolumn{7}{|c|}{$\begin{array}{l}\text { RCTs on the effect of CPAP on blood pressure in } \\
\text { OSA Patients (Alajmi } M \text { et al, 2007) }\end{array}$} \\
\hline Study & $\begin{array}{l}\text { Pati- } \\
\text { ents }\end{array}$ & $\begin{array}{l}\text { AHI } \\
(\text { mean })\end{array}$ & $\begin{array}{l}\text { Systolic } \\
\text { BP } \\
\text { reduc- } \\
\text { tion } \\
(\mathrm{mmHg})\end{array}$ & $\begin{array}{l}\text { Diastolic } \\
\text { BP } \\
\text { reduc- } \\
\text { tion } \\
(\mathrm{mmHg})\end{array}$ & \begin{tabular}{|c} 
Dura- \\
tion \\
of \\
CPAP
\end{tabular} & Control \\
\hline $\begin{array}{l}\text { Barbe et al } \\
2000\end{array}$ & 54 & 55 & 1 & 1 & $\begin{array}{c}6 \\
\text { weeks }\end{array}$ & $\begin{array}{l}\text { Subthera- } \\
\text { peutic CPAP }\end{array}$ \\
\hline $\begin{array}{l}\text { Barnes et al } \\
2002\end{array}$ & 28 & 12.9 & -0.5 & 0.9 & $\begin{array}{c}8 \\
\text { weeks }\end{array}$ & Pill placebo \\
\hline $\begin{array}{l}\text { Monasterio } \\
\text { et al } 2001\end{array}$ & 125 & 20 & 2 & 1 & $\begin{array}{c}6 \\
\text { months }\end{array}$ & $\begin{array}{l}\text { Subthera- } \\
\text { peutic CPAP }\end{array}$ \\
\hline $\begin{array}{l}\text { Pepperell } \\
\text { et al } 2002\end{array}$ & 118 & $\begin{array}{l}\text { Desatu- } \\
\text { ration } \\
\text { index } \\
\text {-AHI37 }\end{array}$ & 3.4 & 3.3 & $\begin{array}{c}1 \\
\text { months }\end{array}$ & $\begin{array}{l}\text { Subthera- } \\
\text { peutic CPAP }\end{array}$ \\
\hline $\begin{array}{l}\text { Usui et al } \\
2005\end{array}$ & 17 & 40.4 & 19.9 & 8.5 & $\begin{array}{c}1 \\
\text { months }\end{array}$ & $\begin{array}{l}\text { Subthera- } \\
\text { peutic CPAP }\end{array}$ \\
\hline $\begin{array}{l}\text { Kaneko } \\
\text { et al } 2003\end{array}$ & 24 & 41.2 & 16 & 1 & $\begin{array}{c}1 \\
\text { months }\end{array}$ & $\begin{array}{l}\text { Subthera- } \\
\text { peutic CPAP }\end{array}$ \\
\hline $\begin{array}{l}\text { Barnes } \\
\text { et al } 2004\end{array}$ & 89 & 21.3 & 0.9 & 0.6 & $\begin{array}{c}3 \\
\text { months }\end{array}$ & $\begin{array}{l}\text { Subthera- } \\
\text { peutic CPAP }\end{array}$ \\
\hline $\begin{array}{l}\text { Campos- } \\
\text { Rodriguez } \\
\text { et al2006 }\end{array}$ & 68 & 58.9 & 0.9 & 0.7 & $\begin{array}{c}4 \\
\text { weeks }\end{array}$ & $\begin{array}{l}\text { Subthera- } \\
\text { peutic CPAP }\end{array}$ \\
\hline $\begin{array}{l}\text { Becker } \\
\text { et al } 2003\end{array}$ & 32 & 63.8 & 10.6 & 11.3 & $\begin{array}{c}9 \\
\text { weeks }\end{array}$ & $\begin{array}{l}\text { Subthera- } \\
\text { peutic CPAP }\end{array}$ \\
\hline $\begin{array}{l}\text { Robinson } \\
\text { et al } 2006\end{array}$ & 32 & $\begin{array}{l}28.1 \\
\text { (Desatu- } \\
\text { ration } \\
\text { index } \\
-\mathrm{AHI} \\
28.1 \text { ) }\end{array}$ & -0.4 & 1.2 & $\begin{array}{c}1 \\
\text { months }\end{array}$ & $\begin{array}{l}\text { Subthera- } \\
\text { peutic CPAP }\end{array}$ \\
\hline
\end{tabular}


normotensive population, the BP lowering effect of CPAP therapy was not evident. Another recurring issue is that of compliance to CPAP therapy. Only studies which reported mean duration of 5 hours/night of CPAP compliance showed any demonstrable reduction in BP.

Another interesting feature of blood pressure profile in patients with OSA is that they do not show the normal $15-20 \%$ fall in blood pressure (nocturnal dipping of BP) seen during sleep. Loredo et al have reported that $85 \%$ of patients with OSA were 'non-dippers'. ${ }^{32}$ Suzuki et al observe that non dippers are at increased risk for cerebrovascular events, cardiac arrhythmias and cardiac hypertrophy. ${ }^{33}$

\section{Treatment trials evaluating vascular outcome}

Buchner et al in a prospective control trial of CPAP therapy in mild-moderate OSA involving 288 patients (209 in treatment arm and 79 in control arm) with fatal and nonfatal vascular events (stroke, acute coronary syndrome) as outcome measures found that $80.3 \%$ of patients in the treatment arm have event free survival at 10 yrs, while the same was $51.8 \%$ in the control arm $(\mathrm{p}<0.001) .{ }^{34}$ In the partly retrospective study by Doherty et al patients with AHI $>15 / \mathrm{Hr}$ was offered CPAP therapy. Patients who were compliant on CPAP were compared with those who were noncompliant on CPAP for death due to vascular events in a 5 years follow up period. There was a significant excess of cardiovascular deaths (nine deaths [14.8\%] vs two deaths [1.9\%], respectively; $\mathrm{p}=0.009$ ) and a nonsignificant increase in cardiovascular morbidity in the untreated group compared to those in the CPAP group. Furthermore, the total number of cardiovascular events (death and new cardiovascular disease combined) was significantly greater in the untreated group compared to that in the CPAP group ( $31 \%$ vs $18 \%$, respectively; $\mathrm{p}<0.05) .{ }^{35}$ Martinez-Garcia et al in their prospective control trial involving acute ischemic stroke patients, PSG was done 2 months after the ictus and patients with AHI 20 or more were offered CPAP.

Similar to Doherty's study, patients tolerant on CPAP was taken as the treatment group (n:15, 29.4\%), while those intolerant on CPAP (n: 36) was followed up as the control and assessed for new vascular events during a 18 months follow up period. Patients on CPAP had 1 vascular event $(6.7 \%)$, while the 'control' arm had

Table 6: OSA \& Stroke: Treatment Trials

\begin{tabular}{|c|c|c|c|c|}
\hline Study & Design \& Pts & Outcome measures & Results & Remark \\
\hline $\begin{array}{l}\text { Buchner et al } \\
\text { AJRCCM } \\
\text { 2007; } 176 \\
\text { CPAP Rx in } \\
\text { mild-moderate } \\
\text { OSA }\end{array}$ & $\begin{array}{l}\text { Prospective controlled trial } \\
288 \text { pts with mild-mod } \\
\text { OSA Rx }: 209 \text {, Control }: 79 \\
\text { Inclusion criteria: mild-mod } \\
\text { OSA patients }\end{array}$ & $\begin{array}{l}\text { Non-fatal vascular event } \\
\text { (Stroke, ACS) } \\
\text { Fatal Vascular event } \\
\text { (Death due for } \\
\text { MI or stroke) }\end{array}$ & $\begin{array}{l}\mathrm{Rx}: 80.3 \% \text { event free } \\
\text { survival at } 10 \mathrm{yrs} \\
\text { Control: } 51.8 \% \\
(\mathrm{P}<0.001) \\
\text { Median } \mathrm{f} / \mathrm{u}: 72 \text { mon } \mathrm{P}< \\
0.001 ; \text { ARR- (absolute } \\
\text { risk reduction) } 28.5 \% \text {; } \\
\text { NNT (number needed } \\
\text { to treat) } / 10 \mathrm{y}-3.5\end{array}$ & $\begin{array}{l}\text { Non-randomized } \\
\text { trial } \\
\text { Control group had } \\
\text { less patients }\end{array}$ \\
\hline $\begin{array}{l}\text { Doherty et al } \\
\text { Chest } 2005\end{array}$ & $\begin{array}{l}\text { Prospective \& Retrospective } \\
\text { cohort study } \\
\text { Inclusion criteria : OSA pts AHI } \\
>15 / \text { hr (Total } 223 \text { included; } 168 \\
\text { for analysis) } \\
\text { Group I : CPAP compliant (107) } \\
\text { Group II : CPAP noncompliant } \\
\text { (n: } 61)\end{array}$ & $\begin{array}{l}\text { Death due to vascular events } \\
\text { Cardiovascular events } 5 \mathrm{yrs} \\
\text { follow-up }\end{array}$ & $\begin{array}{l}\text { Group I : } 2 \text { vascular } \\
\text { deaths } \\
\text { Group II: } 9 \text { vascular } \\
\text { death (6 definite and } \\
3 \text { probable) }(\mathrm{P}=0.3) \\
\text { Cardiovascular events } \\
\text { Group I : } 31 \% \\
\text { Group II: } 18 \%(\mathrm{P}=0.009)\end{array}$ & $\begin{array}{l}\text { Non-randomized } \\
\text { trial } \\
\text { Partly retrospective }\end{array}$ \\
\hline $\begin{array}{l}\text { Martinez- } \\
\text { Garcia et al } \\
\text { Chest 2005:128 }\end{array}$ & $\begin{array}{l}\text { Prospective control trial } \\
\text { Inclusion criteria: Ischemic } \\
\text { stroke pts ( } 2 \text { months after ictus) } \\
\text { PSG }-2 \text { mth after ictus } \\
\text { CPAP offered AHI } \geq 20 \text { (n: } 55) \\
\text { Group I : CPAP tolerant } \\
(15,29.4 \%) \\
\text { Group II: CPAP not tolerating (36) }\end{array}$ & $\begin{array}{l}\text { New Vascular events during } \\
18 \mathrm{mth} \text { f/u }\end{array}$ & $\begin{array}{l}\text { VE } \\
\text { Group I : } 6.7 \% \\
\text { Group II: } 36 \%(P=0.03)\end{array}$ & $\begin{array}{l}\text { Non-randomized } \\
\text { trial } \\
\text { Rx group has less } \\
\text { patients }\end{array}$ \\
\hline
\end{tabular}


14 events $(36 \%) .{ }^{36}$ (Table 6).

There are several concerns regarding the design and methodology of these studies. Apart from the fact that they are nonrandomized, the inclusion criteria for the control group was the highly questionable criteria of 'intolerance' to CPAP and the treatment and control groups were asymmetrical. However, in the context of a host of evidences showing the significance of OSA as a vascular risk, and given the magnitude of the effect size (absolute risk reduction and number needed to treat in the studies by Buchner et al and Martinez-Garcia et al being $28.5 \%$ and 3.5 and $28.3 \% \& 3.4$ respectively), these outcomes should not be ignored. Moreover, it is almost impossible to conduct a placebo controlled RCT with a follow up long enough to demonstrate vascular outcomes with a device as CPAP. The use of sham CPAP or subtherpaeutic CPAP for prolonged period is not feasible, and unethical.

\section{Conclusion}

To conclude, there is overwhelming clinical and experimental evidence implicating sleep-disordered breathing, in particular obstructive sleep apnea as a risk factor of stroke. However, treatment trials with CPAP are limited by methodological issues and the issue of compliance, preventing clear-cut evidence-based treatment recommendation. In clinical practice, it therefore important to evaluate for SDB as a reversible risk factor of stroke and refractory hypertension on an individual basis, and offer the option of appropriate therapy, especially in cases of moderate-to-severe OSA, keeping in mind that the most important limitation in the current treatment options is the issue of compliance.

\section{References}

1. American Academy of Sleep Medicine task force. Sleeprelated breathing disorders in adults: recommendations for syndrome definition and techniques in clinical research. Sleep 1999; 22:667-689

2. Meoli AL, Casey KR, Clark RW, Coleman JA, Fayle RW, Troell RJ et al. The Clinical practice review committee of the American academy of sleep medicine. Hypopnea in sleepdisordered breathing in adults. Sleep 2001; 24:469-470

3. Walter T. McNicholas. The Proceedings of the American Thoracic Society 5:154-160 (2008)

4. Exar EN and Collop NA. The Upper airway resistance syndrome. Chest 1999; 115:1127-1139

5. Davidson TM. The Great Leap Forward: the anatomic basis for the acquisition of speech and obstructive sleep apnea. Sleep Medicine. May 2003; 4:185-194

6. Ip MSM, Tse H-F, Lam B, Tsang KW, Lam W-K. Endothelial function in obstructive sleep apnea and response to treatment. Am J Respir Crit Care Med 2004; 169:348353

7. Lavie L, Vishnevsky A, Lavie P. Evidence for lipid peroxidation in obstructive sleep apnea. Sleep $2004 ; 27: 123-128$

8. Dyugovskaya L, Lavie P, Lavie L. Increased adhesion molecules expression and production of reactive oxygen species in leukocytes of sleep apnea patients. Am J Respir Crit Care Med 2002; 165:934-939

9. Schulz R, Mahmoudi S, Hattar K, Sibelius U, Olschewski $\mathrm{H}$, Mayer K, et al. Enhanced release of superoxide from polymorphonuclear neutrophils in obstructive sleep apnea. Impact of continuous positive airway pressure therapy. Am J Respir Crit Care Med 2000; 162:566-570

10. Vgontzas AN, Papanicolaou DA, Bixler EO, Kales A, Tyson $\mathrm{K}$, Chrousos GP. Elevation of plasma cytokines in disorders of excessive daytime sleepiness: role of sleep disturbance and obesity. J Clin Endocrinol Metab 1997; 82:1313-1316

11. Shamsuzzaman AS, Winnicki $M$, Lanfranchi $P$, Wolk R, Kara T, Accurso V, et al. Elevated C-reactive protein in patients with obstructive sleep apnea. Circulation 2002; 105:2462-2464

12. Ip MS, Lam B, Ng MM, Lam WK, Tsang KW, Lam KS. Obstructive sleep apnea is independently associated with insulin resistance. Am. J. Respir. Crit. Care Med 2002; 165:670-676

13. Wilcox I, McNamara SG, Collins FL, Grunstein RR, Sullivan CE. "Syndrome Z": the interaction of sleep apnea, vascular risk factors, and heart disease. Thorax 1998; 53:S25-S28

14. Eisensehr I, Ehrenberg BL, Noachtar S, Korbett K, Byrne A, MaAuley A and Palabrica T. Platelet activation, epinephrine, and blood pressure in obstructive sleep apnea syndrome. Neurology 1998; 51:188-195

15. Wessendorf TE, Thilmann AF, Wang Y, Schreiber A, Konietzko $\mathrm{N}$ and Teschler $\mathrm{H}$. Fibrinogen and obstructive sleep apnea in ischemic stroke. Am. J. Respir. Crit. Care Med. 162:2032-2042

16. Bokinsky G, Miller Michael, Ault K, Husband P and J Mitchell. Spontaneous platelet activation and aggregation during obstructive sleep apnea and its response to therapy with nasal continuous positive airway pressure. Chest 1995; 108:625-630

17. Young T, Palta M, Dempsey J, Skatrud J, Weber S, Badr S. The occurrence of sleep-disordered breathing among middle-aged adults. N Engl J Med 1993; 328:1230-1235

18. Gislason T, Almqvist M, Eriksson G, Taube A, Boman G. Prevalence of sleep apnea syndrome among Swedish men: an epidemiological study. J Clin Epidemiol 1988; 41:571576.

19. Bassetti C., Aldrich MS, Chervin RD and Quint D. Sleep apnea in patients with transient ischaemic attack and stroke. Neurology 47:1167-1173 
20. Bassetti C and Aldrich MS. Sleep apnea in acute cerebrovascular disease: final report in 128 patients. Sleep 22: $217-223$

21. Harbison J, Ford GA, James OF, Gibson GJ. Sleepdisordered breathing following acute stroke. Q J Med. 2002; 95:741-747

22. Wessendorf TE, Teschler $\mathrm{H}$, Wang $\mathrm{YM}$, Konietzko $\mathrm{N}$, Thilmann AF. Sleep-disordered breathing among patients with first-ever stroke. J Neurol. 2000; 247:41-47

23. Parra O, Arboix A, Bechichb S, Garcia-Eroles L, Montserrat JM, Lopez JA, et al. Time Course of Sleep-related Breathing Disorders in First-Ever Stroke or Transient Ischemic Attack. Am. J. Respir. Crit. Care Med., 2000; 161:375-380

24. Yaggi HK, Concato J, Kernan WN, Lichtman JH, Brass LM, Mohsenin V. Obstructive sleep apnea as a risk factor for stroke and death. New Engl J Med 2005; 353:2034-2041

25. Shahar E, Whitney C, Redline S, Lee ET, Newman AB, Nieto FJ, et al. Sleep-disordered breathing and cardiovascular disease: cross-sectional results of the Sleep Heart Health Study. Am J Respir Crit Care Med 2001; 163: 19-25

26. Valham F, Mooe T, Rabben T, Stenlund H, Wiklund U, Franklin KA. Increased risk of stroke in patients with coronary artery disease and sleep apnea: a 10-year follow-up. Circulation. 2008 Aug 26; 1 18(9):955-60. Epub 2008 Aug 12.

27. Martin JM, Carrizo SJ, Vicente E, Agusti AGN. Long-term cardiovascular outcomes in men with obstructive sleep apnoea-hypopnea with or without treatment with continuous positive airway pressure: an observational study. Lancet 2005; 365:1046-53
28. Peppard PE, Young T, Palta M, Skatrud J. Prospective study of the association between sleep-disordered breathing and hypertension. N Engl J Med 2000; 342:1378-1384

29. Alajmi M, Mulgrew AT, Fox J, Davidson W, Schulzer M, Mak $E$, et al. Impact of continuous positive airway pressure therapy on blood pressure in patients with obstructive sleep apnea hypopnea: A meta-analysis of randomized controlled trials.Lung 2007; 185:67-72.

30. Logan AG, Perlikowski SM, Mente A, Tisler Andras, Tkacova $R$, Niroumand $M$ et al. High prevalence of unrecognized sleep apnea in drug resistant hypertension. J Hypertens. 2001 ; 19:2271-2277.

31. Logan AG, Tkacova R, Perlikowski SM, Leung RS, Tisler A, Floras JS, et al. Refractory hypertension and sleep apnoea: effect of CPAP on blood pressure and baroreflex. Eur Respir J 2003; $21: 241-247$.

32. Loredo JS, Ancoli-Israel S, Dimsdale JE. Sleep quality and blood pressure dipping in OSA. Am J Hypertens. 2001; 14:887-892

33. Suzuki M, Guilleminault C, Otsuka K, Shiomi T. Blood pressure "dipping" and "non-dipping in OSA patients. Sleep $1996 ; 19: 382-387$

34. Buchner NJ, Sanner BM, Borgel J, Rump LC. Continuous positive airway pressure treatment of mild to moderate obstructive sleep apnea reduces cardiovascular risk. Am J Respir Crit Care Med 2007; 176:1274-1280

35. Doherty LS, Kiely JL, Swan V, RgN, McNicholas WT. Long term effects of nasal continuous positive airway pressure therapy on cardiovascular outcomes in sleep apnea syndrome. Chest 2005; 127:2076-2084

36. Martinez-Garcia MA, Galiano-Blancard Rafael, RomanSanchez P, Soler-Cataluna J, Salcedo-Maiques E. Continuous positive airway pressure treatment in sleep apnea prevents new vascular events after ischemic stroke. Chest 2005; 128:2123-2129 